\title{
Identification of differentially expressed genes in developing cotton fibers (Gossypium hirsutum L.) through differential display
}

\author{
Saima Iqbal \\ Plant Biotechnology Division \\ National Institute for Biotechnology and Genetic Engineering \\ Jhang Road, Faisalabad, Pakistan \\ Tel: 92412651475 ext 263 \\ Fax: 92412651472 \\ E-mail: saimaqbl@yahoo.com \\ Aftab Bashir* \\ Plant Biotechnology Division \\ National Institute for Biotechnology and Genetic Engineering \\ P.O. Box 577, Jhang road \\ Faisalabad, Pakistan \\ Tel: 9241265147579 ext 232 \\ Fax: 92412651472 \\ E-mail: aftabbashir@nibge.org \\ Hafiza Masooma Naseer \\ Plant Biotechnology Division \\ National Institute for Biotechnology and Genetic Engineering \\ Jhang Road, Faisalabad, Pakistan \\ Tel: 92412651475 ext 233 \\ Fax: 92412651472 \\ E-mail: masoomasajid@yahoo.com

Moddassir Ahmed
Plant Biotechnology Division
National Institute for Biotechnology and Genetic Engineering
Jhang Road, Faisalabad, Pakistan
Tel: 92412651475 ext 262
Fax: 92412651472
E-mail: moddassir@nibge.org \\ Kauser A. Malik \\ Food and Agriculture \\ Planning Commission \\ P-Block, Room \# 404 \\ Pak Secretariat \\ Islamabad, Pakistan \\ Tel: 92519201974 \\ Fax: 92419206993 \\ E-mail: kamalik@comsats.net.pk
}

Financial support: This work was supported by the Pakistan Academy of Sciences, Higher Education Commission (Pakistan) PhD student grant and ASPL-II project of MinFAL (Ministry of Food Agriculture and Live Stock).

Keywords: cotton fiber, differentially expressed transcripts, Gossypium hirsutum, non-radioactive.

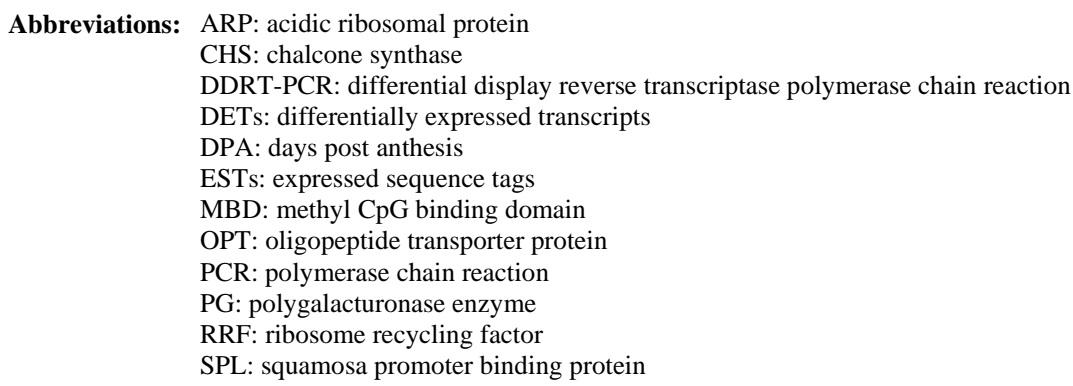

*Corresponding author 
Cotton fibers are differentiated, non-dividing cells that originate from the epidermal layer of developing ovules. To identify genes involved in cotton fiber development, we performed non-radioactive differential display reverse transcriptase PCR (DDRT-PCR) on the purified mRNA. This technique was tested on mRNA isolated from five different developmental stages of cotton fiber including 0, 5, 10, 15 and 20 DPA (days after pollination). The mRNA purified from total RNA was reversibly transcribed using three anchored oligo-dT primers. Polymerase chain reaction (PCR) amplification of each cDNA preparation was carried out in combination with seven arbitrary primers. The amplified products were resolved on $1 \%$ agarose gel containing ethidium bromide. DNA was extracted from seventeen differentially expressed bands and cloned in $\mathrm{pTZ57R/T}$ vector. The sequencing and BLAST search analysis indicated that 12 of the differentially expressed genes matched the previously characterized genes, while 3 of them matched the uncharacterized sequences of cotton fiber expressed sequence tags (ESTs) reported previously to be associated with cotton fiber and 2 of the clones had homology with putative proteins. The technique can be used to efficiently identify differentially expressed genes and can be expanded to large scale studies by increasing the number of random decamers.

Cotton is an important crop that yields the natural fiber used by the textile industry. The commercial cotton fiber is a product of Malvaceous plants of genus Gossypium. Cotton fibers consist of single cells that range $30-40 \mathrm{~mm}$ in length and $15 \mu \mathrm{m}$ in thickness. Fiber development process comprises of four overlapping stages: fiber initiation, fiber elongation, secondary cell wall deposition and maturation/dehydration (Basra and Malik, 1984). The fiber initiation stage occurs around the time of anthesis from -3 to +1 days post anthesis (DPA) and is characterized by the enlargement and protrusion of epidermal cells from the ovular surface. Approximately 30\% of the ovular epidermal cells differentiate into lint fiber. Several days later, another class of fiber cells which are known as fuzz fibers or linters start growing but those do not grow longer than $15 \mathrm{~mm}$ (Kim and Triplett, 2001; Ji et al. 2003; Ruan et al. 2003). Fiber cells keep elongating from first day of anthesis to approximately 21-26 DPA. Solute transport into the fiber cells during cellular expansion is mostly through reversible gating of plasmodesmata (Ruan et al. 2001). Fiber cells almost synchronously enter into secondary wall deposition phase. Successive layers of cellulose are deposited until the wall is 3-4 $\mu \mathrm{m}$ thick. Mature cotton fiber comprises of about 95\% pure cellulose. Cellulose biosynthesis continues until fiber completely matures. This phase of fiber development has not been investigated in detail largely due to low protein and nucleic acid recovery from cells. At approximately 45-60 DPA, the seed capsule dehisces and the fibers quickly dehydrate (Kim and Triplett, 2001). The degree of overlap between the phases of elongation and secondary wall thickening varies between cultivars and is dependent on environmental conditions. The time of onset of secondary wall deposition may affect final fiber length (Jaswandala et al. 1977). The economic importance of cultivated cotton has stimulated extensive studies on fiber development. Fiber properties, particularly length, strength and fineness, require further improvement for higher quality end products.

Fiber development is a complex process. The four fiber development stages (initiation, elongation, secondary cell wall deposition and maturation) are controlled by distinct sets of genes ( $\mathrm{Ji}$ et al. 2003). A large number of genes have been predicted to be involved in the regulation of fiber development (Smart et al. 1998; Li et al. 2002). The DFCI cotton gene index at the computational Biology and Functional Genomics Laboratory at the Dana-Farber Cancer Institute and Harvard School of Public Health (http://compbio.dfci.harvard.edu/tgi/cgi-

bin/tgi/gimain.pl?gudb=cotton) has a database covering 211,397 cotton expressed sequence tags (ESTs). About $60 \%$ of the EST sequences comprise of cotton fiber genes mostly from DD (G. raimondii), AA genome ( $G$. arboretum)and G. hirsutum species (http://compbio.dfci.harvard.edu/tgi/temp/cottest.libs). The 55,673 unique cotton fiber sequences including TCs and singletons have $26 \%$ entries specific to cotton fiber development with unknown functions (Yang et al. 2006). The EST collection has greatly been centered on different cotton species and new sequences are frequently reported (Gao et al. 2007; Xu et al. 2007). The research groups working on fiber development are focused on the identification of complete sets of genes and the pathways involved in fiber development to improve the quality and quantity of cotton fiber.

The goal of identifying genes expressed at different fiber developmental stages and controlling the four major events of fiber development could partly be achieved by RNA differential display technology. This technique is basically based on differential display reverse transcriptasepolymerase chain reaction (DDRT-PCR). Its procedure was first described by Liang and Pardee (1992). This method has the advantage of technical simplicity, lower bias against rare messages and a requirement for low quantities of mRNA starting material.

A problem with the original method of Liang and Pardee (1992) is the high number and small size of amplification products that are resolved on polyacrylamide gels. The differentially displayed bands on the polyacrylamide gels may have heterogeneous mixture of amplified products (Welsh et al. 1992) and a cloned cDNA may not represent the differentially expressed gene of interest. Moreover, this radiographic method incorporates higher number of errors in band selection and yield of DNA from polyacrylamide 
gel are usually too low for efficient cloning of the desired products. Several modifications of the original technique have been reported with some solutions to the key problems. We have modified the recent approach developed by Kim et al. (2004). The technique has been modified to utilize mRNA for DDRT-PCR instead of using total RNA and the products of DDRT-PCR can be resolved and observed on $1 \%$ agarose gels stained with ethidium bromide. The number of low molecular weight amplification products are reduced, thus yielding fewer bands on the gel and lower chances of getting heterogeneous population of polymerase chain reaction (PCR) products of same size. The differentially expressed genes are easily identified, may be eluted from the gel and cloned into T/A based cloning vectors. This report describes 17 differentially expressed genes from cotton fiber identified by DDRT-PCR using mRNA as a template.
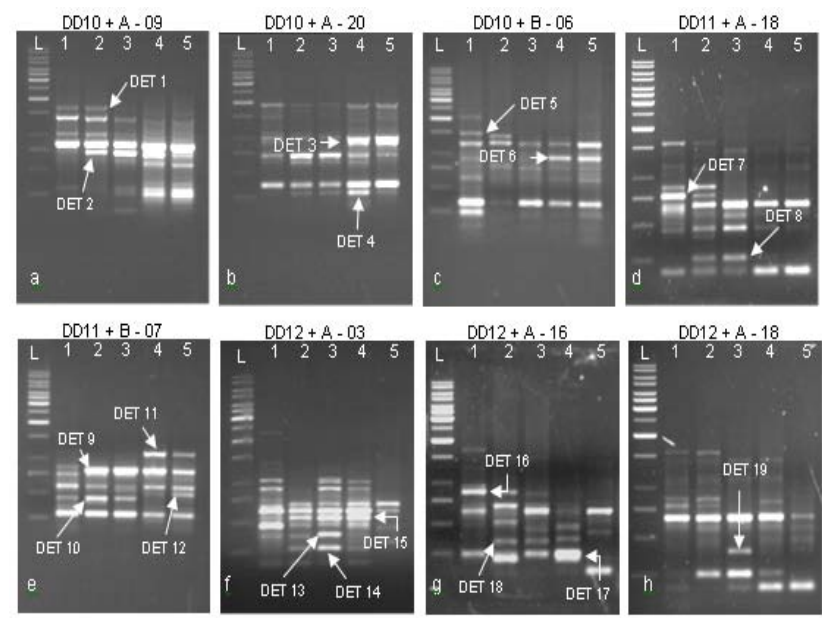

Figure 1. Results of DDRT-PCR for the identification of DETs. Lanes 1-5 represent different fiber development stages (0 DPA, 5 DPA, 10 DPA, 15 DPA and 20 DPA) respectively. PCR amplification was performed using one of the three anchored primer in combination with arbitrary primer as indicated at the top of each picture. Arrows indicate DETs. L represents $1 \mathrm{~Kb}$ DNA ladder (Fermentas, USA).

\section{MATERIALS AND METHODS}

\section{Plant material and total RNA extraction}

Cotton (Gossypium hirsutum L.) var.CIM 707 was used in this study. On the onset of flowering each flower was tagged as 0 DPA. The samples were collected at five different fiber development stages for RNA extraction from the specific tissues i.e., 0 DPA (Stage 1; ovules and fiber), 5 DPA (Stage 2; fibers only), 10 DPA (Stage 3; fibers only), 15 DPA (Stage 4; fibers only) and 20 DPA (Stage 5; fibers only). Fresh ovules/cotton bolls at the given stages were collected in liquid nitrogen. Total RNA was extracted using plant RNA purification reagent (Invitrogen, USA) following the manufacturers instructions. Agarose gel electrophoresis was used to test the integrity and purity of the extracted RNA.

\section{Isolation of messenger RNA and CDNA synthesis}

The messenger RNA was isolated from total RNA using oligo (dT) cellulose columns (MRC, USA) according to manufacturer instructions. The loaded columns were washed with binding buffer and mRNA was eluted. The eluted mRNA was precipitated and dissolved in DEPC treated water. Messenger RNA from five fiber developmental stages were reverse transcribed to cDNA using Revert Aid $\mathrm{H}^{-}$First Strand cDNA Synthesis kit, (Fermentas, USA). Three reverse transcription reactions were carried out for each mRNA using three different anchored $\left(T_{11} M\right)$ primers (where $M$ may be $G, C$ or $A$ ). The products of reverse transcriptions (cDNA) were stored at $-20^{\circ} \mathrm{C}$ for differential display PCR amplifications.

\section{DDRT-PCR}

PCR amplification of each cDNA was carried out in combination with one of the seven arbitrary primers and one of the three anchored primer (Table 1) providing 21 combinations. PCR was carried out in a final reaction volume of $50 \mu \mathrm{l}$ containing $2.5 \mu \mathrm{l}(50 \mathrm{ng} / \mu \mathrm{l})$ of first strand cDNA, $5 \mu \mathrm{l}$ of 10x PCR buffer, $4 \mu \mathrm{l} \mathrm{MgCl} 2$ (25 $\mathrm{mM}), 1 \mu \mathrm{l}$ of dNTPs (10 mM each), $2 \mu \mathrm{l}$ of anchored primer (250 ng/ $\mu \mathrm{l}), 8 \mu \mathrm{l}$ of arbitrary primer $(100 \mathrm{ng} / \mu \mathrm{l})$, $0.5 \mu$ of Taq DNA Polymerase (5 U/ $\mu$; Fermentas, USA), $27 \mu \mathrm{l}$ double distilled $\mathrm{H}_{2} \mathrm{O}$. The PCR amplification protocol included first cycle at $94^{\circ} \mathrm{C}$ for 4 min; $36^{\circ} \mathrm{C}$ for $2 \mathrm{~min} ; 72^{\circ} \mathrm{C}$ for $2 \mathrm{~min}$ followed by 39 cycles at $94^{\circ} \mathrm{C}$ for $1 \mathrm{~min} ; 36^{\circ} \mathrm{C}$ for $1 \mathrm{~min} ; 72^{\circ} \mathrm{C}$ for $1 \mathrm{~min}$ and a final extension step at $72^{\circ} \mathrm{C}$ for $10 \mathrm{~min}$. The amplified PCR products were resolved on $1 \%$ agarose gel and stained with ethidium bromide.

\section{Cloning and sequencing of differentially expressed genes}

The differentially expressed bands were excised from the gel and extracted by QIAGEN gel extraction kit. The eluted DNA fragments were cloned using InstaClone kit (Fermentas, USA) and transformed into E. coli TOP10 cells. The plasmid DNA from the purified clones were sequenced using M13(-20) forward/M13 reverse primers and BigDye terminator v 3.1 kit on ABI Prism 310 Genetic analyzer (Applied Biosystems, USA).

\section{Analysis of the differentially expressed transcripts (DETs)}

The nucleotide sequences were BLAST searched for blastn and/or blastx algorithms in NCBI. The Clusters of Orthologous Group of proteins COG/KOG were identified 
Table 1. Primer sequences for CDNA synthesis and DDRT-PCR.

\begin{tabular}{|c|c|c|}
\hline Use & Anchored Primers & Primer Sequences \\
\hline CDNA & DD10 & 5' TTTTTTTTTTTG 3' \\
\hline CDNA & DD11 & 5' TTTTTTTTTTTC 3' \\
\hline CDNA & DD12 & 5' TTTTTTTTTTTA 3' \\
\hline Random Decamers (Arbitrary Primers) & Primer Sequences \\
\hline PCR & A-03 & 5' AGTCAGCCAC 3' \\
\hline PCR & A-09 & 5' GGGTAACGCC 3' \\
\hline PCR & A-16 & 5'AGCCAGCGAA 3' \\
\hline PCR & A-18 & 5'AGGTGACCGT 3' \\
\hline PCR & A-20 & 5' GTTGCGATCC 3' \\
\hline PCR & B-06 & 5' TGCTCTGCCC 3' \\
\hline PCR & B-07 & 5' GGTGACGCAG 3' \\
\hline
\end{tabular}

at NCBI (http://www.ncbi.nlm.nih.gov/COG) and KEGG Orthology (KO) at http://www.genome.jp/dbgetbin/www_bfind?orthology.

\section{RESULTS AND DISCUSSION}

Differential display technique was used to detect the genes that are differentially expressed during cotton fiber development. The developmental stages were selected to cover the major period involved in fiber development and spanned fiber initiation (-3 to 1 DPA), elongation (5-15 DPA) and secondary cell wall deposition (15-25 DPA) (Basra and Malik, 1984). The total RNA was isolated from five selected fiber developmental stages at 0, 5, 10, 15 and 20 DPA. The DDRT-PCR indicated several differentially transcribed genes (Figure 1), of which seventeen DETs, amplified by different anchored and arbitrary primer pairs (Table 1), were selected, cloned and sequenced. Sequence analysis of the cloned DETs showed 12 of them to represent genes that have been previously characterized (Table 2), while 5 of the transcripts represent genes of unknown function. The 17 DETs fall into 3 groups and are discussed below.

\section{Group 1: House-keeping genes}

Fiber cells are single epidermal extensions possessing the entire regular (house keeping) as well as specialized metabolic activities. The transcript level of the house keeping genes may vary during fiber development due to the differences in metabolic activities being carried out with fiber development. We detected six transcripts (DET 4,
DET 7, DET 9, DET 13, DET 14, DET 16) representing house keeping genes through the differential display technique. These transcripts code for proteins involved in i) translation, ribosomal structure and biogenesis, ii) secondary metabolites biosynthesis, transport and catabolism and iii) energy production and conversion (Table 2). The DET 7 was detected between 0-5 DPA and had homology with chalcone synthase (CHS). CHS (secondary metabolite) is a plant-specific polyketide synthase important for the biosynthesis of anti-microbial isoflavonoid phytoalexins, anthocyanin floral pigments and flavonoid inducers of Rhizobium nodulation genes (Contessotto et al. 2001). The detection of CHS transcripts at early fiber development stage is in accordance with the reported tentative consensus sequences (TC) derived from ESTs of G. hirsutum ovules, GH_TM0 (Yang et al. 2006). This enzyme is unlikely to play a role in development of pigment production in white cotton fibers. The detection of CHS transcripts at 0 DPA and 5 DPA might be from the ovular and early differentiating fiber cells.

The ribosome recycling factor (RRF) (DET 4) expressed at 5-15 DPA. The transcript level of this gene appears highest at 15 DPA (Figure 1b). The RRF is involved mainly in the disassembly of the translation termination complex. The RRF has also been reported to stimulate in-vitro protein synthesis. An eight-fold increase in in vitro lysozyme synthesis was observed when supplemented with RRF at limited amounts of ribosomes. In the absence of RRF, ribosomes remain mRNA-bound at the termination codon (Selmer et al. 1999). The gradual increase in the DET 4 transcript level during the fiber development may indicate the stimulation of ribosomal machinery to accelerate the metabolic pathways to meet the demands of the fast growing fiber cell. The BLAST search indicated that this transcript does not have homology to the reported fiber ESTs. It might represent a singleton indicating rare gene transcript. DET 14 transcripts were observed from 5-10 DPA (Figure 1f). This transcript has homology to the structural constituents of ribosomes that impart structural integrity to the ribosome complex. The ribosomes, structural constituents of ribosomes and ribonucleoprotein complexes have been reported for increased expression in early developing fiber initials (Taliercio and Boykin, 2007). The maximum level of this transcript at $10 \mathrm{DPA}$ is in coordination with the RRF and possibly enhances the translational efficiency in the fast growing fiber cells.

DET 9 transcript was detectable between 5-20 DPA (Figure 1e) and its DNA sequence indicated homology with NADH dehydrogenase subunit 1 (ndh1) also known as NADH oxidoreductase. It is present in a membrane embedded subcomplex having gene products from ndhA-ndhG complex that is possibly involved in plastoquinone reduction. This protein is also involved in generation of cellular energy in the form of ATP by building the electrochemical potential in electron transport chain (Burrows et al. 1998; Sazanov et al. 1998). The detection of 
Table 2. DETs in cotton fiber and their identities.

\begin{tabular}{|c|c|c|c|c|c|c|c|c|}
\hline \multirow[t]{2}{*}{ DEGs } & \multirow{2}{*}{$\begin{array}{l}\text { Primer } \\
\text { pair }\end{array}$} & \multicolumn{5}{|c|}{ DPA } & \multirow{2}{*}{$\begin{array}{l}\text { Homology with reported genes / Homology with fiber } \\
\text { EST's }\end{array}$} & \multirow{2}{*}{$\begin{array}{l}\text { Size \& Accession \# / COG or KOG } \\
\text { (group) }\end{array}$} \\
\hline & & 0 & 5 & 10 & 15 & 20 & & \\
\hline DET 2 & $\begin{array}{l}\text { DD10 + } \\
\text { A09 }\end{array}$ & - & + & + & + & + & $\begin{array}{l}\text { Polygalacturonase (NM118513)/GH_TM0 ovule and } \\
\text { GA Ed0037E01f, 7-10 DPA fiber cDNA lib. EST's }\end{array}$ & 717 bp/EF453638/Nil \\
\hline DET 3 & \multirow[t]{2}{*}{$\begin{array}{l}\mathrm{DD} 10+ \\
\mathrm{A} 20\end{array}$} & - & - & - & + & + & Uncharacterized / Nil & 832 bp/EF453648/Nil \\
\hline DET 4 & & - & + & + & + & - & RRF (YP545636)/Nil & $\begin{array}{l}29 \mathrm{bp} / \mathrm{EF} 453644 / \text { Translation, ribosomal } \\
\text { structure and bioqenesis (COG0233) }\end{array}$ \\
\hline DET 5 & \multirow[t]{2}{*}{$\begin{array}{l}\text { DD10 + } \\
\text { B06 }\end{array}$} & + & + & - & - & - & Uncharacterized/GH_TM0 cDNA library clone DT575216 & $1210 \mathrm{bp} / \mathrm{EF} 453643 / \mathrm{Nil}$ \\
\hline DET 6 & & - & - & - & + & + & $\begin{array}{l}\text { endo-1,3-beta-glucanase (D88416)/ CM058G04 GH fiber } \\
\text { cDNA Lib. EST's }\end{array}$ & $437 \mathrm{bp} / \mathrm{EF} 453649 / \mathrm{Nil}$ \\
\hline DET 7 & \multirow[t]{2}{*}{$\begin{array}{l}\text { DD11 }+ \\
\text { A18 }\end{array}$} & + & + & - & - & - & CHS (DQ026297)/GH_TM0 ovule cDNA lib. EST's & $\begin{array}{l}773 \mathrm{bp} / \mathrm{EF} 453639 / \mathrm{Secondary} \\
\text { metabolites biosynthesis, transport and }\end{array}$ \\
\hline DET 8 & & - & + & + & - & - & $\begin{array}{l}\text { Uncharacterized/GA_Ed0037E01f , 7-10 DPA fiber lib, } \\
\text { EST's }\end{array}$ & 248 bp/EF453647/Nil \\
\hline DET 9 & \multirow[t]{4}{*}{$\begin{array}{l}\text { DD11+ } \\
\text { B07 }\end{array}$} & - & + & + & + & + & $\begin{array}{l}\text { B. napus mitochondrial DNA. NADH dehydrogenase subunit } \\
\text { I like protein (AP006444)/Nil }\end{array}$ & $\begin{array}{l}819 \text { bp/EF453646/Energy production } \\
\text { and conversion (COG1005) }\end{array}$ \\
\hline $\begin{array}{l}\text { DET } \\
10\end{array}$ & & + & + & + & - & - & $\begin{array}{l}\text { SPL (AJ011623) GH_TM0 ovule cDNA library clone } \\
\text { DT556696 GA Eb0015B06f. 7-10 DPA fiber librarv }\end{array}$ & 443 bp/EF453640/Nil \\
\hline $\begin{array}{l}\text { DET } \\
11\end{array}$ & & - & - & - & + & + & $\begin{array}{l}\text { Hevea brasiliensis sucrose transporter } 1 \\
\text { (DO985466)/EST118 Pima 3-79 fiber normalized cDNA }\end{array}$ & $\begin{array}{l}1155 \mathrm{bp} / \mathrm{EF} 453641 \\
\text { Sucrose transport and related proteins }\end{array}$ \\
\hline $\begin{array}{l}\text { DET } \\
12\end{array}$ & & - & - & - & - & + & Erythrobacter litoralis Hypothetical Prot (YP458095)/Nil & 531 bp/EF453642/Nil \\
\hline $\begin{array}{l}\text { DET } \\
13\end{array}$ & \multirow[t]{3}{*}{$\begin{array}{l}\mathrm{DD} 12+ \\
\mathrm{A} 03\end{array}$} & + & + & + & - & - & $\begin{array}{l}\text { Arabidopsis thaliana ATOPT7 oligopeptide transporter } \\
\text { (NM117145)/GR } \quad \text { Ea Gossypium raimondii cDNA clone }\end{array}$ & $\begin{array}{l}376 \text { bp/EF440360/Membrane transport } \\
\text { (KO3305, COG3104) }\end{array}$ \\
\hline $\begin{array}{l}\text { DET } \\
14\end{array}$ & & - & + & + & - & - & $\begin{array}{l}\text { Ribosomal L29e protein Medicago truncatula } \\
\begin{array}{ll}\text { (ABE83196)/GA } \quad \text { Ea0007K10f Gossypium arboreum 7-10 }\end{array}\end{array}$ & $\begin{array}{l}286 \mathrm{bp} / \mathrm{EF} 440361 \\
\text { Translation, ribosomal structure and }\end{array}$ \\
\hline $\begin{array}{l}\mathrm{DET} \\
15\end{array}$ & & - & + & + & + & - & $\begin{array}{l}\text { methyl-CpG-binding domain Arabidopsis thaliana } \\
\text { (NP563971)/GR Ea Gossypium raimondii cDNA clone }\end{array}$ & 472 bp/EF440359/Nil \\
\hline DET16 & \multirow[t]{2}{*}{$\begin{array}{l}\text { DD12 + } \\
\text { A16 }\end{array}$} & + & + & + & - & - & $\begin{array}{l}\text { Ribosomal protein } 605 \text { Medicago truncatula } \\
\text { (ABE83633)/GR } \quad \text { Ea Gossypium raimondii cDNA clone }\end{array}$ & $\begin{array}{l}686 \mathrm{bp} / \mathrm{EF} 453637 \\
\text { Translation, ribosomal structure and }\end{array}$ \\
\hline $\begin{array}{l}\text { DET } \\
17\end{array}$ & & - & + & + & + & - & $\begin{array}{l}\text { Hypothetical protein Vitis vinifera (CAN72450)/CM072D03 } \\
\text { Gossvpium hirsutum fiber 5-10 DPA cDNA lib clone }\end{array}$ & 252 bp/EF453636/Nil \\
\hline $\begin{array}{l}\text { DET } \\
19\end{array}$ & $\begin{array}{l}\text { DD12 + } \\
\text { A18 }\end{array}$ & - & - & + & - & - & $\begin{array}{l}\text { Arabidopsis thaliana TIP1 clone NM122042/GR } \\
\text { Gossvium raimondii cDNA clone C0126102 GH LSL }\end{array}$ & $\begin{array}{l}382 \mathrm{bp} / \mathrm{EF} 453645 \text { General function } \\
\text { prediction protein (KOG0509) }\end{array}$ \\
\hline
\end{tabular}

+ : Presence of DET.

$\therefore$ Absence of DET.

COG/KOG: Clusters of orthologous groups.

DET's: Differentially expressed transcript.

DPA: Days post anthesis.

ESTs: Expressed sequence tags.

GA: Gossypium arboreum.

GB: Gossypium barbadence.

GH: Gossypinm hirsutum.

GR: Gossypium ramandii.

Prot:: Protein.

its transcripts from 5-20 DPA indicates that this gene is hardly expressed at the ovular stage and its expression is elevated with the elongation of fiber cells to meet the energy requirements during the fiber development process.

DET 13 was detected at 0-10 DPA (Figure 1f) and has homology with the oligopeptide transporter protein (OPT)
(Table 2). The OPTs are integralmembrane proteins with 12 to 14 transmembrane domains. The presenceof multiple OPTs in Arabidopsis is believed to be important in the transport of small peptides across cellular membranes (Koh et al. 2002). The gene ontology studies with the ESTs from early developing fiber have indicated the presence of transcripts responsible for protein transport (Taliercio and 
Boykin, 2007). The presence of this transporter may reflectthe regular activities of the cell involving small peptide transport across the fastly growing membranous structures within the fiber cell. DET 16 was detected between 0-10 DPA (Figure 1g). This transcript shows homology with the 60S acidic ribosomal protein (ARP) (Table 1). ARPs are highly conserved phosphoproteins in eukaryotic organisms. They participate in translation regulation by interacting with eEF-2 elongation factors in the peptide elongation process. ARP interaction with elongation factors has been demonstrated to speed up protein synthesis in eukaryotic organisms (Aguilar et al. 1998; Montoya-García et al. 2002). The inhibition of the expression of mRNA encoding acidic ribosomal phosphorproteins (P1 and P2) in malignant tissues by treatment with gonadotrophin releasing hormone has been reported to cause reduction in peptide elongation and thus reduced cell proliferation rate (Chen et al. 2002). The ovular cells differentiated into fiber cells are fast elongating cells. The presence of ARP transcripts in the fast elongating fiber cells might indicate that this gene is supporting the translational efficiency of the cell for meeting the required metabolic rate.

\section{Group 2: Fiber development related genes}

Different fiber development specific genes are expected to express at the four fiber development stages ( $\mathrm{Wu}$ et al. 2006). The differential display technique applied in this study helped to identify six transcripts (DET 2, DET 6, DET 10, DET 11, DET 15 and DET 19) involved in fiber development. The proteins coded by the reported homologues of these transcripts are given in Table 1. DET 2 transcript was detected from 5-20 DPA (Figure 1a). The translated product of DET 2 indicated that it codes for polygalacturonase/pectinase (PG) enzyme. PG is involved in degradation of pectic cell wall components. The role of PG in the depolymerization of pectic polymers in fruit cell walls has been well demonstrated (Chun and Huber, 1998; White, 2002; Abu-Goukh and Bashir, 2003). During fiber elongation, polysaccharides and proteins are secreted to the inner surface of the growing cell wall, where they assemble into a network that is mechanically strong. The presence of PG enzymes renders the cell wall extensible by degrading the polysaccharides associated with the cell wall until the cells cease to grow. Therefore, PG seems to have a direct role in fiber cell elongation. DET 6 has similarity with endo-1,3-beta-glucanase and its transcripts were detected from 15-20 DPA (Figure 1c). Opening and closing of plasmodesmata connection plays a key role in maintaining the turger pressure in co-ordination with the $\mathrm{K}+$ and sucrose transporters within the growing fiber cells (Arioli, 2005; Wu et al. 2006). The endo-1,3-beta-glucanase is involved in the degradation of callose plug that blocks the plasmodesmata opening and maintains the turgor pressure within the growing fiber cell. The appearance of DET 6 from 15 DPA onwards indicates that the turgor pressure of developing cotton fibers of $G$. hirsutum L var. CIM707 might be lost at 15 DPA. The callose plug in G. barbadense remains closed for 20-21 days (Arioli, 2005), which produces long fibers. An early digestion of the callose plug and loss of turgor pressure in G. hirsutum might be a reason for comparatively shorter fiber length. This finding indicates that the release of turgor pressure in the developing cotton fibers ( $G$. hirsutum L. var. CIM707) is at least 5 days earlier than for $G$. barbadense and may play an important role in limiting fiber length. DET10 transcripts were detected from 0-10 DPA (Figure 1e) with maximum transcript level at 5 DPA. This gene has homology with squamosa promoter binding protein (SPL), a family of structurally diverse genes encoding putative transcription factors found apparently only in plants. The Myb and homeodomain transcription factors have been reported in the initiation of fiber development in the ESTs established from cotton ovules of wild and lintlessfuzzless mutants. The transcription factors appearling later (5-10 DPA) have also been detected and proposed to play some developmental controls in fiber elongation rather than initiation (Wu et al. 2006). The distinguishing characteristic of the SPL gene family is the SBP-box encoding a conserved protein domain of 76 amino acids, which is responsible for the interaction with DNA. Some SPL genes are constitutively expressed, while transcriptional activity of others is under developmental control. SBP-box genes are proposed to play a role in the control of plant development (Cardon et al. 1999). The detection of SPL gene in the developing fibers is an indication of the transcriptional control of development specific genes in fibers.

DET 11 was detected from 15-20 DPA (Figure 1e) and showed homology with sucrose transporter type 1 . In addition to plasmodesmata openings the sucrose is also transported across the basal membrane of developing fibers by the action of the sucrose transporter and is converted to UDP-glucose, which in turn is a precursor for the synthesis of cellulose, a major component of the cotton fiber (Xu et al. 2007). The secondary cell wall synthesis initiates at about 15 DPA and it requires an abundant supply of sucrose for cellulose synthesis to fill the cell and make a twisted rigid structure (Ruan et al. 2003). The presence of sucrose transporter transcripts at the late stage of fiber elongation corresponds with the secondary cell wall deposition in the growing fiber cells. DET 15 appeared at $0-15$ DPA (Figure 1f). This transcript has homology with methyl-CpG-binding domain and identity with $G$. ramondii fiber cDNA library clone (Table 2). The discovery of a group of proteins containing a methyl $\mathrm{CpG}$ binding domain (MBD) greatly contributed to the understanding of methylation induced gene silencing (Hendrich and Bird, 1998; Zemach and Grafi, 2003). DNA methylation is involved in the induction of gene silencing either by blocking the binding of the transcription factors to their cognate recognition sequences or by recruiting transcriptional repressors or various factors that induce chromatin compaction (Bird, 2002). These proteins appear to act as structural proteins which recruit a 
variety of histone deacetylase complexes and chromatin remodeling factors, leading to chromatin compaction and consequently to transcriptional repression (Ballestar and Wolffe, 2001; Wade, 2001). The expression of MBD (DET 15) in 0-15 DPA fibers suggests that this protein might be involved initially in silencing the transcription initiation factors and then switching off the genes involved in fiber cell elongation at the later stage of secondary cell wall deposition.

DET 19 is well detected at 10 DPA and shows much weaker signal at 5 and 15 DPA (Figure 1h). This gene has homology with TIP1 (Table 2). TIP1 has been reported to be involved in the polar growth of root hairs and pollentubes in A. thaliana. The mutation in this gene causes an excessive initial swelling from which multiple and branched hairs emerge. This suggests that TIP1 plays a role in restricting hair initiation to a single site on the initial swelling (Ryan et al. 1998). Two mechanisms controlling fiber elongation, diffused or polar growth, have been generally discussed (Tiwari and Wilkins, 1995; Gou et al. 2007). The transcripts of TIP1 gene are weakly detectable at 5 DPA (Figure 1h) which indicates that the coding protein might be expressed on or after 5 DPA. It may be presumed that before 5 DPA the fiber cells might be expanding by diffused growth mechanism but as the cells expand the polar/tip growth mechanism could be the secondary mean of fiber elongation.

\section{Group 3: Uncharacterized genes}

Developing cotton fibers of G. hirsutum may express about 36,000 genes including house keeping and fiber development specific genes. It has been reported that a major proportion of the fiber development specific genes still remain to be characterized (Wilkins et al. 2005). There were five transcripts (DET 3, DET 5, DET 8, DET 12 and DET 17) identified through differential display PCR, which did not have homology to the non-redundant DNA database and the Clusters of Orthologous Genes at NCBI. However, similarity of three transcripts (DET 5, DET 8 and DET 17) was observed with ESTs reported for developing cotton fibers, while two of them (DET 3 and DET 12) appear to be the new sequences. Both these transcripts are detected from 15-20 DPA (Figure 1b and Figure 1e) that is the time of secondary cell wall deposition in developing fibers. Most of the reported fiber ESTs have been derived before the onset of secondary cell wall deposition. The function of these genes remains to be determined but it is likely that these genes may have some role at the later stage of fiber cell growth.

Numerous genomic scale studies have been undertaken recently to clearly identify the differentially expressed genes and the relavent pathways involved in the development of cotton fibers (Wilkins et al. 2005; Yang et al. 2006; Gao et al. 2007; Gou et al. 2007; Taliercio and Boykin, 2007; Xu et al. 2007). The complete picture on the metabolic pathways involved in the development of cotton fiber through genomic scale expression profiling of the transcripts is limited by a high percentage of transcripts that still need to be characterized with respect to the coded proteins. However, the majority of genes involved in fiber initiation, elongation and morphogenesis have been identified. The genome scale expression profiling through microarray is a high throughput technology which is limited to the majority of research groups due to high cost of equipment and expensive materials.

Differential display methods generally utilize denaturing polyacrylamide gels and radioactive detection techniques. Radioactive compounds impose health hazards and their use is not feasible in every laboratory. Moreover, recovering a unique radio-labeled DNA species from dried polyacrylamide gels is technically challenging, and often results in the failure to isolate and clone a particular cDNA representative (Lohmann et al. 1995). Many nonradioactive differential display methods have been described which incorporate different detection methods for the DETs. These methods include silver staining (Gottschlich et al. 1997), fluorescently-labeled oligonucleotides (Ito et al. 1994), biotinylated primers (Tagle et al. 1993) and ethidium bromide stained agarose gels (Rompf et al. 1997; Jefferies et al. 1998; Gromova et al. 1999; Ahmed et al. 2000; Kim et al. 2004). The differential display methods utilizing polyacrylamide gels are good to visualize the highest number of DETs but the recovery and cloning of amplified products is hard due to the low amounts of amplification products retrievable from the thin gels. The recovery of RT-PCR products from ethidium bromide stained gels is easier and provides enough material for cloning purposes. The technique was modified to obtain clean and clear amplification products utilizing the mRNA as a template for cDNA synthesis instead of using total RNA. The amplification products obtained through this modification could be easily detected on standard $1 \%$ agarose gel stained with ethidium bromide. All the analyzed clones represented coding sequences, which indicated that the amplifications were from cDNA obtained from the mRNA population. We identified 17 DETs including some reported fiber development specific genes and two new transcripts that appear at late stages of fiber development by using only 21 combinations of the three anchored and seven random primers. A higher number of random decamers may be utilized to detect a greater number of differentially expressed genes from developing cotton fibers.

\section{REFERENCES}

ABU-GOUKH, Abu-Bakr and BASHIR, Hind A. Changes in pectic enzymes and cellulase activity during guava fruit ripening. Food Chemistry, November 2003, vol. 83, no. 2, p. 213-218.

AGUILAR, Raúl; MONTOYA, Leonel and JIMENEZ, Estela Sánchez de. Synthesis and phosphorylation of maize 
acidic ribosomal proteins: implications in translational regulation. Plant Physiology, January 1998, vol. 116, no. 1, p. 379-385.

AHMED, N.; SIDDIQUI, A.A. and AHMED, A. DDRTPCR: Use of agarose gels for detection of amplified products. Molecular Vision, July 2000, vol. 6, p. 144-147.

ARIOLI, T. Genetic engineering for cotton fiber improvement. Pflanzenschutz-Nachrichten Bayer, January 2005, vol. 58, p. 140-150.

BALLESTAR, Esteban and WOLFFE, Alan P. Methyl CpG-binding proteins: targeting specific gene repression. European Journal of Biochemistry, January 2001, vol. 268, no. 1 , p. 1-6.

BASRA, A.S. and MALIK, C.P. Development of the cotton fiber. International Review of Cytology, 1984, vol. 89, p. 65-113.

BIRD, Adrian. DNA methylation patterns and epigenetic memory. Genes and Development, January 2002, vol. 16, no. 1 , p. 6-21.

BURROWS, Paul A.; SAZANOV, Leonid A.; SVAB, Zora; MALIGA, Pal and NIXON, Peter J. Identification of a functional respiratory complex in chloroplasts through analysis of tobacco mutants containing disrupted plastid ndh genes. The EMBO Journal, February 1998, vol. 17, no. 4, p. 868-876.

CARDON, Guillermo; HOEHMANN, Susanne; KLEIN, Joachim; NETTESHEIM, Klaus; SAEDLER, Heinz and HUIJSER, Peter. Molecular characterization of the Arabidopsis SBP-box genes. Gene, September 1999, vol. 237, no. 1, p. 91-104.

CHEN, Alon; KAGANOVSKY, Ella; RAHIMIPOUR, Shai; BEN-AROYA, Nurit; OKON, Eli and KOCH, Yitzhak. Two forms of gonadotropin-releasing hormone $(\mathrm{GnRH})$ are expressed in human breast tissue and overexpressed in breast cancer: a putative mechanism for the antiproliferative effect of GnRH by down-regulation of acidic ribosomal phosphoproteins P1 and P2. Cancer Research, February 2002, vol. 62, no. 4, p. 1036-1044.

CHUN, Jong-Pil and HUBER, Donald J. Polygalacturonase-mediated solubilization and depolymerization of pectic polymers in tomato fruit cell walls: Regulation by $\mathrm{pH}$ and ionic conditions. Plant Physiology, August 1998, vol. 117, no. 4, p. 1293-1299.

CONTESSOTTO, Miriam G.G.; MONTEIRO-VITORELLO, Claudia B.; MARIANI, Pilar D.S.C. and COUTINHO, Luiz L. A new member of the chalcone synthase (CHS) family in sugarcane. Genetic and Molecular Biology, January 2001, vol. 24, no. 1-4, p. 257-261.
GAO, Peng; ZHAO, Pi-Ming; WANG, Juan; WANG, HaiYun; WU, Xiao-Min and XIA, Gui-Xian. Identification of genes preferentially expressed in cotton fibers: A possible role of calcium signaling in cotton fiber elongation. Plant Science, June 2007, vol. 173, no. 1, p. 61-69.

GOTTSCHLICH, S.; GOEROEGH, T.; FOLZ, B.J.; LIPPERT, B.M. and WERNER, J.A. Optimized differential display and reamplification parameters for silver staining. Research Communications in Molecular Pathology and Pharmacology, August 1997, vol. 97, no. 2, p. 237-240.

GOU, Jin-Ying; WANG, Ling-Jian; CHEN, Shuang-Ping; HU, Wen-Li and CHEN, XIAO-Ya. Gene expression and metabolite profiles of cotton fiber during cell elongation and secondary cell wall synthesis. Cell Research, May 2007, vol. 17, no. 5, p. 422-434.

GROMOVA, Irina; GROMOV, Pavel and CELIS, Julio E. Identification of true differentially expressed mRNAs in a pair of human bladder transitional cell carcinomas using an improved differential display procedure. Electrophoresis, February 1999, vol. 20, no. 2, p. 241-248.

HENDRICH, Brian and BIRD, Adrian. Identification and characterization of a family of mammalian methyl-CpGbinding proteins. Molecular and Cellular Biology, November 1998, vol. 18, no. 11, p. 6538-6547.

ITO, Takashi; KITO, Keiji; ADATI, Naoki; MITSUI, Yuko; HAGIWARA, Hisashi and SAKAKI, Yoshiyuki. Fluorescent differential display: arbitrarily primed RT-PCR fingerprinting on an automated DNA sequencer. FEBS Letters, September 1994, vol. 351, no. 2, p. 231-236.

JASWANDALA, R.T.; SING, Y.D. and CHINOY, J.J. Auxin metabolism in developing cotton hairs. Journal of Experimental Botany, October 1977, vol. 28, no. 5, p. 11111116.

JEFFERIES, D.; BOTMAN, M.; FARQUHARSON, C.; LESTER, D.; WHITEHEAD, C.C.; THORP, B.H. and HOUSTON, B. Cloning of differentially regulated genes from chondrocytes using agarose gel differential display. Biochimica et Biophysica Acta, March 1998, vol. 1396, no. 3, p. 237-241.

JI, Sheng-Jian; LU, Ying-Chun; FENG, Jian-Xun; WEI, Gang; LI, Jun; SHI, Yong-Hui; FU, Qiang; LIU, Di; LUO, Jing-Chu and ZHU, Yu-Xian. Isolation and analyses of genes preferentially expressed during early cotton fiber development by subtractive PCR and CDNA array. Nucleic Acid Research, May 2003, vol. 31, no. 10, p. 2534-2543.

KIM, Hee Jin and TRIPLETT, Barbara A. Cotton fiber growth in planta and in vitro. Models for plant cell elongation and cell wall biogenesis. Plant Physiology, December 2001, vol. 127, no. 4, p. 1361-1366. 
KIM, Yun-Jee; KWAK, Chae-ll; GU, Young-Yun; HWANG, In-Taek and CHUN, Jong-Yoon. Annealing control primer system for identification of differentially expressed genes on agarose gels. BioTechniques, March 2004, vol. 36, no. 3, p. 424-434.

KOH, Serry; WILES, Amy M.; SHARP, Joshua S.; NAIDER, Fred R.; BECKER, Jeffrey M. and STACEY, Gary. An oligopeptide transporter gene family in Arabidopsis. Plant Physiology, January 2002, vol. 128, no. 1, p. 21-29.

LI, Xue-Bao; CAI, Lin; CHENG, Ning-Hui and LIU, JianWei. Molecular characterization of the cotton GhTUB1 gene that is preferentially expressed in fiber. Plant Physiology, October 2002, vol. 130, no. 2, p. 666-674.

LIANG, P. and PARDEE, A.B. Differential display of eukaryotic messenger RNA by means of the polymerase chain reaction. Science, August 1992, vol. 257, no. 5072, p. 967-971.

LOHMANN, J.; SCHICKLE, H. and BOSCH, T.C.G. REN-display, a rapid and efficient method for nonradioactive differential display and mRNA isolation. BioTechniques, February 1995, vol. 18, no. 2, p. 200-202.

MONTOYA-GARCIA, Leonel; MUÑOZ-OCOTERO, Verónica; AGUILAR, Raúl and JIMENEZ, Estela Sánchez de. Regulation of acidic ribosomal protein expression and phosphorylation in maize. Biochemistry, August 2002, vol. 41, no. 31, p. 10166-10172.

ROMPF, R. and KAHL, G. mRNA differential display in agarose gels. BioTechniques, July 1997, vol. 23, no. 1, p. 28-32.

RUAN, Yong-Ling; LLEWELLYN, Danny J. and FURBANK, Robert T. The control of single celled cotton fiber elongation by developmentally reversible gating of plasmodesmata and coordinated expression of sucrose and $\mathrm{K}^{+}$transporters and expansin. Plant Cell, January 2001, vol. 13, no. 1, p. 47-60.

RUAN, Yong-Ling; LLEWELLYN, Danny J. and FURBANK, Robert T. Suppression of sucrose synthase gene expression represses cotton fiber cell initiation, elongation and seed development. The Plant Cell, April 2003, vol. 15, no. 4, p. 952-964.

RYAN, Eoin; GRIERSON, Claire S.; CAVELL, Alison;STEER, Martin and DOLAN, Liam. TIP1 is required for both tip growth andnon-tip growth in Arabidopsis. New Phytologist, January 1998, vol. 138, no. 1, p. 49-58.

SAZANOV, Leonid A.; BURROWS, Paul A. and NIXON, Peter J. The plastid $n d h$ gene code for an NADH-specific dehydrogenase: Isolation of a complex I analogue from pea thylakoid membranes. Proceeding of the National Academy of Sciences of the United States of America, February 1998, vol. 95, no. 3, p. 1319-1324.

SELMER, Maria; AL-KARADAGHI, Salam; HIROKAWA, Go; KAJI, Akira and LILJAS, Anders. Crystal Structure of Thermotoga maritima ribosome recycling factor: A tRNA mimic. Science, December 1999, vol. 286, no. 5448, p. 2349-2352.

SMART, Lawrence B.; VOJDANI, Fakrieh; MAESHIMA, Masayoshi and WILKINS, Thea A. Genes involved in osmoregulation during turgor-driven cell expansion of developing cotton fibers are differentially regulated. Plant Physiology, April 1998, vol. 116, no. 4, p. 1539-1549.

TAGLE, Danilo A.; SWAROOP, Manju; LOVETT, Michael and COLLINS, Francis S. Magnetic bead capture of expressed sequences encoded within large genomic segments. Nature, February 1993, vol. 361, no. 6414, p. 751-753.

TALIERCIO, Earl W. and BOYKIN, Deborah. Analysis of gene expression in cotton fiber initials. BMC Plant Biology, May 2007, vol. 7, p. 22.

TIWARI, Suresh C. and WILKINS, Thea A. Cotton (Gossypium hirsutum) seed trichomes expand via diffuse growing mechanism. Canadian Journal of Botany, May 1995, vol. 73, no. 5, p. 746-757.

WADE, Paul A. Methyl CpG-binding proteins and transcriptional repression. BioEssays, December 2001, vol. 23, no. 12, p. 1131-1137.

WELSH, J.; CHADA, K.; DALAL， S.; CHENG，D.; RALPH, D. and MCCLELLAND, M. Arbitrarily primed PCR fingerprinting of RNA. Nucleic Acids Research, October 1992, vol. 20, no. 19, p. 4965-4970.

WHITE, Philip J. Recent advances in fruit development and ripening: an overview. Journal of Experimental Botany, October 2002, vol. 53, no. 377, p. 1995-2000.

WILKINS, T.; ARPAT, A. and SICKLER, B. Cotton fiber genomics: developmental mechanism. PflanzenschutzNachrichten Bayer, January 2005, vol. 58, p. 119-139.

WU, Yingru; MACHADO, Adriane C.; WHITE, Rosemary G.; LLEWELLYN, Danny J. and DENNIS, Elizabeth S. Expression profiling identifies genes expressed early during lint fibre initiation in cotton. Plant and Cell Physiology, January 2006, vol. 47, no. 1, p. 107-127.

XU, Yu; LI, Hong-Bin and ZHU, Yu-Xian. Molecular Biological and Biochemical studies reveal new pathways important for cotton fiber development. Journal of Integrative Plant Biology, January 2007, vol. 49, no. 1, p. 69-74. 
YANG, Samuel S.; CHEUNG, Foo; LEE, Jinsuk J.; HA, Misook; WEI, Ning E.; SZE, Sing-Hoi; STELLY, David M.; THAXTON Peggy; TRIPLETT, Barbara; TOWN, Christopher D. and CHEN, Z. Jeffrey. Accumulation of genome-specific transcripts, transcription factors and phytohormonal regulators during early stages of fiber cell development in allotetraploid cotton. The Plant Journal, September 2006, vol. 47, no. 5, p. 761-775.

ZEMACH, Assaf and GRAFI, Gideon. Characterization of Arabidopsis thaliana methyl-CpG-binding domain (MBD) proteins. The Plant Journal, June 2003, vol. 34, no. 5, p. 565-572.

WILKINS, T.; ARPAT, A. and SICKLER, B. Cotton fiber genomics: developmental mechanism. PflanzenschutzNachrichten Bayer, January 2005, vol. 58, p. 119-139.

WU, Yingru; MACHADO, Adriane C.; WHITE, Rosemary G.; LLEWELLYN, Danny J. and DENNIS, Elizabeth S. Expression profiling identifies genes expressed early during lint fibre initiation in cotton. Plant and Cell Physiology, January 2006, vol. 47, no. 1, p. 107-127.

$\mathrm{XU}, \mathrm{Yu}$; LI, Hong-Bin and ZHU, Yu-Xian. Molecular Biological and Biochemical studies reveal new pathways important for cotton fiber development. Journal of Integrative Plant Biology, January 2007, vol. 49, no. 1, p. 69-74.

YANG, Samuel S.; CHEUNG, Foo; LEE, Jinsuk J.; HA, Misook; WEI, Ning E.; SZE, Sing-Hoi; STELLY, David M.; THAXTON Peggy; TRIPLETT, Barbara; TOWN, Christopher D. and CHEN, Z. Jeffrey. Accumulation of genome-specific transcripts, transcription factors and phytohormonal regulators during early stages of fiber cell development in allotetraploid cotton. The Plant Journal, September 2006, vol. 47, no. 5, p. 761-775.

ZEMACH, Assaf and GRAFI, Gideon. Characterization of Arabidopsis thaliana methyl-CpG-binding domain (MBD) proteins. The Plant Journal, June 2003, vol. 34, no. 5, p. 565-572. 